\title{
A NOTE ON DETERMINING THE SPATIAL AND PRODUCT EXTENT OF A MARKET
}

\author{
Noel D. Uri"
}

\begin{abstract}
In this paper an approach is used for defining the nature and extent of a geographic market and a product market relying on the concept of instantaneous causality. The market(s) for rice is (are) used for the empirical implementation of the technique. The results, based on both domestic (United States) and world prices, suggest that the extent of the geographic market changed between 1968 and 1986. This has obvious policy implications.
\end{abstract}

\section{Introduction}

Endeavoring to delineate the nature and extent of competition in the market for various commodities is important for a variety of reasons. Such information is significant in formulating marketing strategies and in developing pricing decisions. Alternatively, in antitrust considerations, both the product market and geographic market are relevant. ${ }^{1}$ Thus, in the case of a geographic market, if prices of a commodity supplied by different economic agents tend to uniformity (given allowances for transportation cost) and if prices outside the market are independently determined, ${ }^{2}$ then a geographic market is the area in which collusion can result in higher prices for the commodity in question. ${ }^{3}$

The examination of prices and their movements as indicative of a market has received renewed interest in the past several years. ${ }^{4}$ The central argument suggests that price is an ideal measure to focus on when considering the extent of a product and/or geographic market because it is the variable by which competition is revvealed most directly. Information about changing demand and supply conditions is transmitted to both consumers and producers through prices. For example, enhanced profit opportunities are revealed by increasing price-cost margins, and rivals, endeavoring to take advantage of supra normal returns, will increase output with the result that price, and hence profit, will return to the competitive level. This

\footnotetext{
- Resources and Technology Division, Economic Research Service, U.S. Department of Agriculture. The views expressed are those of the author and do not necessarily represent the policies of the U.S. Department of Agriculture or the views of other Department of Agriculture staff members.
}

argument is cast in terms of the perfectly competitive model of neoclassical microeconomic theory. Unfortunately, this perfect world does not exist. Such things as product differentiation, imperfect information, transactions costs, expectations, and technological innovation all are contradictory to the ideal conditions needed to use the perfectly competitive market model. ${ }^{5}$

The activities of the real world, however, have not been neglected by economic practitioners. For example, Jevons (1879) noted that price differences exist for the same item and suggested that this difference arises "from extraneous circumstances such as imperfect knowledge by consumers of the market." The competitive significance of imperfect substitutes that would assist in identifying distinct boundaries was examined by Robinson (1969), Chamberlin (1962) and Kaldor (1934). Kaldor, for example, refined the notion of substitutability to a scale of cross-elasticities across imperfect substitutes. He suggested that different producers do not sell either "identical" or different products but rather "more or less" different products where the demand confronting them is neither completely sensitive nor completely insensitive to the prices charged by the producers. Consequently, the gaps that were postulated to bound a market need not be recognized equally by all producers within the market since all producers need not be equally sensitive to changes of prices of imperfect substitutes. Gaps can appear in different places for different brands during different phases of the business cycle, for different magnitudes of price changes of substitutes, and for different conditions in the markets of the different consumers.

Economic theory does not suggest that commodities making up a relevant market must exhibit identical prices. Rather, the factors posited by Jevons are more relevant. Jevons contends that, when attempting to delineate a market, the variation in the price of any good or service will tend to affect, in the same direction, the price of all like goods or services. Commodities, for example, need not be physically identical nor would one expect their prices always to be equal. But prices will move together over time.

It might be the case that the prices of competing commodities are different, but if the conditions of demand and exchange are interdependent, the ratio of their prices, all other things equal, will be constant over time. This 
observation gives rise to the conclusion by Areeda and Turner (1978, p. 352) that "close price relations among products over a substantial period of time are sufficient to establish a strong presumption that the products should be included in the same market." It must be remembered that the degree of price uniformity and the extent to which different goods or services constitute a single market will be dependent on the relevant cross-price elasticities which, in turn, are a function of the direct (own) price elasticity for the good or service (Horowitz, 1977). This latter factor should be apparent in the price correlations. There are a number of limitations, however, in using simple price correlations to infer anything about the extent of the product or geographic market. Foremost among the limitations is that simple price correlations do not imply causality (Granger and Newbold, 1977). For example, two price series that possess significant upward trends due to general inflationary pressure will exhibit a relatively high positive correlation. Such trends must be removed before performing analyses for inferential purposes. Another shortcoming is that simple correlation analysis does not consider the time dimension. Consequently, the fact that two commodities, for example, may be distinct at a given point in time yet are becoming unified over time (though not necessarily in an easily identifiable fashion) would be missed.

In order to overcome these limitations to defining a geographic market and a product market, an approach has been developed based on the notion of instantaneous causality. The approach addresses the shortcomings referred to above and is easy to implement. A complete overview of the procedure is not warranted. That is provided elsewhere. ${ }^{6}$ A cursory review of the relevant considerations is provided however.

Consider two price series, $P_{1}$ and $P_{2}$, which have representations as univariate linear processes that can be written in autoregressive form as

$$
\left[\begin{array}{cc}
F(B) & 0 \\
0 & G(B)
\end{array}\right]\left[\begin{array}{l}
P_{1 t} \\
P_{2 t}
\end{array}\right]=\left[\begin{array}{l}
u_{t} \\
v_{t}
\end{array}\right]
$$

where $F(B)$ and $G(B)$ are polynomials in the lag operator $B$ defined by $B^{j} y_{t}=y_{t, j}$.

Following Haugh (1972), a joint model of the univariate residuals can be derived from this form which is given as

$$
\left[\begin{array}{ll}
a_{1}(B) & a_{2}(B) \\
a_{3}(B) & a_{4}(B)
\end{array}\right]\left[\begin{array}{c}
u_{t} \\
v_{t}
\end{array}\right]=\left[\begin{array}{l}
e_{1 t} \\
e_{2 t}
\end{array}\right]
$$

where $a_{1}, a_{2}, a_{3}$ and $a_{4}$ are polynomials in the lag operator and where all of the operators are one sided. For example,

$$
a_{1}(B)=\sum_{j=0}^{\infty} a_{1 j} B^{j}
$$

Moreover, $a_{10}=a_{40}=1$.

Taking $\mathrm{a}_{20}=\mathrm{E}\left(\mathrm{e}_{1 \mathrm{t}} \mathrm{e}_{2 \mathrm{~s}}\right)=0$, it follows that instantaneous causality exists if and only if $\mathrm{a}_{30}$ does not equal zero. ${ }^{7}$ Simple correlations cannot be used to demonstrate instantaneous causality.

The second equation of relationship (2) can be rewritten as

$$
v_{t}=\sum_{j \geq 0}\left(-a_{3 j}\right) u_{t-j}+\sum_{j>0}\left(-a_{4 j}\right) v_{t-j}+e_{2 t}
$$

Now it can be concluded that instantaneous causality exists if and only if the current period observation on $\mathbf{v}_{t}$ is related to the current period observation on $u_{\mathrm{c}}$. This forms the basis of the statistical test employed. That is, it must be ascertained, for the market(s) under consideration, whether $a_{30}$ is statistically different from zero. In particular, to implement the test empirically, the data series must be suitably transformed (i.e., as in equation (1)) and the residual white noise series (i.e., both the $u_{t}$ and the $v_{t}$ ) used in a regression analogous to equation (4). The finding of statistical significance on the coefficient $a_{30}$ permits the conclusion that instantaneous causality exists.

This test is applied in what follows to a specific agricultural commodity, namely rice, to determine (1) whether there are different geographic markets for rice or whether there is in fact a single world market for the commodity, and (2) to determine whether there are different product markets. It is important to remember that two seemingly different products will be considered as part of the same market (either geographic or product) only if instantaneous causality holds, and this will be the case only if the criterion discussed above is satisfied.

Before turning to the implementation of the test, the rice market and the data used in the analysis are discussed.

\section{The Product}

Rice is the primary food for over half of the population of the world. Rice produced in the United States currently accounts for 19 percent of all rice shipped in international trade, but for only 1.3 percent of world production. Other major exporters of rice include Thailand (with about 34 percent of the total in 1987) and Pakistan (with about 8.9 percent of the total in 1987). ${ }^{8}$

There are three general varieties of rice grown in the world - short grain, medium grain, and long grain. Various regions of exporting countries tend to concentrate on one, 
or at most two, types. In the United States, for example, producers in Arkansas, Texas and Mississippi grow mostly long grain rice while California and Louisiana growers lead in medium grain production. Thailand, on the other hand, grows mostly long grain rice. The decision on which type of grain to plant is a function of soil conditions, weather, crop yield, and world market conditions. ${ }^{9}$

In general, the world rice industry has a relatively simple market structure. The production of rice is much more restricted geographically than production of most other field crops and rice changes hands fewer times between farmers and ultimate consumers. The normal movement from farmer to consumer includes drying and storage, milling and processing, and distribution.

A variety of factors have influenced the price of rice in the U.S. market and in the rest-of-the-world market. (Note the implicit assumption that there are two different markets.) For example, the export price of rice rose 60 percent on average in 1972/1973 due to floods, droughts, civil disturbances and disease in major rice producing regions. Similar movements in the price of rice can be observed during the decades of the 1970s and 1980s. As production decreased due to such things as floods and droughts, rice prices rose and when production increased, the prices rose. (The reader interested in following the movements in rice prices over this period is referred to various issues of the U.S. Department of Agriculture's Rice: Situation and Outlook Report.)

One factor that has had an important influence on rice prices in the United States (and, as will be argued below, on the extent of the geographic market) has been U.S. government programs affecting the price received by farmers. ${ }^{10}$ Between 1955 and 1972, rice support prices were above the world price level. This had the effect, as will be shown below, of isolating the U.S. market from factors affecting world rice prices and hence of narrowing the scope of the market for U.S. produced rice. As noted above, there was a worldwide drop in production of rice in 1971 and 1972 that brought a rapid rise in prices in the autumn of 1972. Rice prices in the United States nearly tripled by the middle of crop year 1973 . This, plus a change in the 1976 United States rice program, made domestic price levels more market oriented.

The substance of these foregoing considerations on the movements in rice prices over the period 1968 through 1986 is that they provide a background against which the test for the extent of both the product market and the geographic market can be conducted. An analysis of the rice market(s) in the United States and the world will be performed by examining rice prices (four price series) at three milling centers (Arkansas, Houston, and Louisiana) in the United States and the Thailand milled rice price $(100$ percent first grade) f.o.b. Bangkok. The U.S. rice types considered include Arkansas medium grain rice, Houston long grain rice, Louisiana medium grain rice, and Louisiana long grain rice. All of the data were taken from Rice: Qutlook and Situation Report (U.S. Department of Agriculture, various issues). The data are monthly and cover the period January 1968 through December 1986 (i.e., 228 observations). ${ }^{11}$

Before addressing the problem of defining the extent of the rice market empirically, a short digression on the importance of looking at the specific agricultural commodity (i.e., rice) is warranted. Interest in the definition of the rice market is prompted by recent instances in which this concern arose in antitrust matters involving California rice millers. In 1982 the proposed acquisition of Pacific International Rice Mills, Inc. (PIRMI) by Early California Industries, the owner of Comet Rice, was abandoned after the Antitrust Division of the U.S. Department of Justice (DOJ) announced its intention to file an antitrust suit. When Rice Growers Association of California (RGA) (the largest California miller) acquired PIRMI (the third largest) in 1984, the Antitrust Division initiated litigation that was successful in forcing a divestiture. ${ }^{12}$ From the public record of these cases, it is possible to discern the market definition used by the DOJ in determining that these acquisitions would be anticompetitive. It was argued that the product market was medium grain rice (the predominant type of rice grown in California) and that the geographic market was the states of the Pacific region of the United States. The market so defined would show high concentration at the milling level. The combined market share of the four largest rice millers - RGA, PIRMI, Comet and Farmers' Rice Cooperative - was given as 95 percent. The combined market share of RGA and PIRMI was given as 51 percent. In accepting the market definition of the DOJ, the acquisitions would seem to pose a genuine competitive concern. If the long and medium grain rice produced and milled in the southern rice-producing states (accounting for about 90 percent of all rice produced in the United States) and if the rice exported from countries in the rest of the world were included in the relevant market, it would be less plausible to argue that the acquisitions would create or enhance market power. If a broader market definition had been adopted by the court, the outcome of the RGA case might have been different. ${ }^{13}$

\section{Empirical Results}

If there is only a single geographic and product market for rice, it would be expected that the prices of all types of rice in the various geographic locations would exhibit a close relationship (in the fashion discussed in the 
section on instantaneous causality) to one another.

In order to implement the test for instantaneous causality, the filters $F(B)$ and $G(B)$ of relationship (1) were estimated. The filter estimates, then were used to estimate the vector $\left(u_{\mathrm{t}}, v_{\mathrm{p}}\right)$. Subsequently, $\mathrm{v}^{\mathrm{t}}$ was regressed on lagged values of $v$ and on current period and lagged values of $u$.

Table 1 reports the filters estimated by the approach of Box and Jenkins (1971) for each of the series of rice prices. In each instance the conventional chi-square test was used to ensure that the residuals were reduced to white noise.

The vector $(0, \theta)$ (i.e., the estimate of the vector from equation (4)) was obtained simply by comparing fitted and actual values from the filters with conventional backcasts used to obtain initial period values.

Before reporting the estimation results, one final consideration is in order. Given the impact of U.S. government programs on domestic rice prices until 1972, it was critical to segment the data into two time periods - one covering 1968 through 1972 (i.e., 60 observations) and the other covering 1973 through 1986 (i.e., 168 observations). This was done for the remainder of the analysis. The filters (i.e., the $F(B)$ and $G(B)$ ), however, were the same throughout the entire sample period. An analysis (along the lines of the tests suggested by Brown, Durbin and Evans (1975)) did not reveal any structural change in the estimates between the two periods.
The estimation results for all combinations of the residual price series (i.e., 40 combinations) for relationship (4) where $j$ was even of moderate size were quite voluminous. Consequently, only a selected number of price residual series combinations for various locations are reported. Results for other combinations are mentioned briefly. Moreover, only those results where $\mathrm{j}$ was permitted to range from 0 to 12 are presented. Since the choice of $j$ was arbitrary, it is interesting to note that the outcome of the analysis did not change when $j$ was allowed to range up to 24. The residuals from each price series were paired separately to all remaining series (e.g., the Arkansas medium grain rice price residual series (AM) was paired to the Houston long grain rice price residual series (HL), the Louisiana medium grain rice price residual series (LM), the Louisiana long grain rice price residual series (LL), and the Thailand rice price residual series (TH)). The estimates of the coefficients were obtained via classical least squares. ${ }^{14}$ The results for a limited number of series combinations for the 1968-1972 period are given in Table $2 \mathrm{a}$ and for the 1973-1986 period, in Table $2 \mathrm{~b}$. (The other regression results are available from the author.) Additionally, the $a_{4 j}$ are not given since they never are statistically significant (i.e., if the filters are properly identified and estimated). ${ }^{15}$

Instantaneous causality cannot be rejected statistically at the 95 percent level for any of the paired combina-

Table 1

Price Series Filters

\begin{tabular}{|c|c|}
\hline Series & $\begin{array}{l}\text { Estimated filterse,b,c } \\
\text { (in autoregressive form) }\end{array}$ \\
\hline $\begin{array}{l}\text { 1. Arkansas Medium Grain } \\
\text { Rice Price }\end{array}$ & $\begin{array}{cc}(1-B)\left(1-0.2854 B^{19}\right)(1-0.5694 ~ B)^{-1} \\
(0.0671) & (0.0557)\end{array}$ \\
\hline $\begin{array}{l}\text { 2. Houston Long Grain } \\
\text { Rice Price }\end{array}$ & $\begin{array}{c}(1-B)\left(1-0.3843 \mathrm{~B}+0.2333 \mathrm{~B}^{11}\right)^{-1} \\
(0.0619) \quad(0.0635)\end{array}$ \\
\hline $\begin{array}{l}\text { 3. Louisiana Medium Grain } \\
\text { Rice Price }\end{array}$ & $\begin{array}{cc}(1-B)\left(1-0.2501 B^{19}\right)(1-0.3820 ~ B)^{-1} & (0.0720)\end{array}$ \\
\hline $\begin{array}{l}\text { 4. Louisiana Long Grain } \\
\text { Rice Price }\end{array}$ & 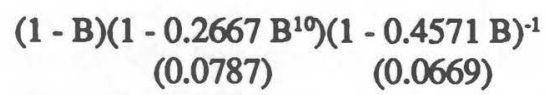 \\
\hline $\begin{array}{l}\text { 5. Thailand } 100 \% \text { First } \\
\text { Grade Rice Price }\end{array}$ & $\begin{array}{c}(1-B)(1-0.1342 B)^{-1} \\
(0.0323)\end{array}$ \\
\hline
\end{tabular}

2 Standard errors of the estimates in parentheses.

${ }^{b}$ Note that $B$ is general operator notation. That is, $B \mathbf{z}_{\mathrm{q}}=\mathbf{z}_{\mathrm{t}: \mathrm{i}}$.

c All residual series were reduced to white noise based on a Chi-square test with at least 36 degrees of freedom. 
Table 2a

Regression Results for Rice Price Residual Series: 1968-1972"

\begin{tabular}{|c|c|c|c|c|c|c|c|c|c|c|c|c|c|c|c|}
\hline $\begin{array}{l}\text { Rice price residual } \\
\text { series (dependent } \\
\text { variable - explanatory } \\
\text { variable)(c) }\end{array}$ & $\gamma_{0}$ & $\boldsymbol{\gamma}_{1}$ & $\boldsymbol{\gamma}_{2}$ & $\gamma_{3}$ & $\gamma_{4}$ & $\gamma_{s}$ & $\gamma_{6}$ & $\boldsymbol{\gamma}_{\boldsymbol{7}}$ & $\gamma_{6}$ & $\boldsymbol{\gamma}_{0}$ & $\gamma_{10}$ & $\gamma_{11}$ & $\gamma_{12}$ & $F^{e}$ & $\mathbf{R}^{2}$ \\
\hline AM-HL & $\begin{array}{c}0.56 \\
(0.19)\end{array}$ & $\begin{array}{c}0.23 \\
(0.21)\end{array}$ & $\begin{array}{c}0.07 \\
(0.21)\end{array}$ & $\begin{array}{l}-0.08 \\
(0.22)\end{array}$ & $\begin{array}{c}0.08 \\
(0.22)\end{array}$ & $\begin{array}{c}0.10 \\
(0.23)\end{array}$ & $\begin{array}{c}0.09 \\
(0.23)\end{array}$ & $\begin{array}{c}0.08 \\
(0.24)\end{array}$ & $\begin{array}{c}0.16 \\
(0.24)\end{array}$ & $\begin{array}{c}0.04 \\
(0.25)\end{array}$ & $\begin{array}{c}0.03 \\
(0.26)\end{array}$ & $\begin{array}{c}0.04 \\
(0.27)\end{array}$ & $\begin{array}{c}0.06 \\
(0.27)\end{array}$ & 36.41 & 0.9358 \\
\hline AM-LM & $\begin{array}{c}0.61 \\
(0.25)\end{array}$ & $\begin{array}{c}0.08 \\
(0.22)\end{array}$ & $\begin{array}{c}0.09 \\
(0.22)\end{array}$ & $\begin{array}{c}0.14 \\
(0.23)\end{array}$ & $\begin{array}{c}0.07 \\
(0.23)\end{array}$ & $\begin{array}{l}-0.03 \\
(0.23)\end{array}$ & $\begin{array}{l}0.05 \\
0.24)\end{array}$ & $\begin{array}{c}0.01 \\
(0.25)\end{array}$ & $\begin{array}{c}0.09 \\
(0.26)\end{array}$ & $\begin{array}{c}0.06 \\
(0.26)\end{array}$ & $\begin{array}{c}0.08 \\
(0.27)\end{array}$ & $\begin{array}{c}0.10 \\
(0.27)\end{array}$ & $\begin{array}{l}-0.11 \\
(0.29)\end{array}$ & 28.61 & 0.8002 \\
\hline AM-LL & $\begin{array}{c}0.63 \\
(0.21)\end{array}$ & $\begin{array}{c}0.04 \\
(0.21)\end{array}$ & $\begin{array}{c}0.09 \\
(0.21)\end{array}$ & $\begin{array}{c}0.07 \\
(0.22)\end{array}$ & $\begin{array}{c}0.05 \\
(0.24)\end{array}$ & $\begin{array}{l}-0.08 \\
(0.24)\end{array}$ & $\begin{array}{c}0.02 \\
(0.26)\end{array}$ & $\begin{array}{l}-0.04 \\
(0.26)\end{array}$ & $\begin{array}{l}-0.01 \\
(0.27)\end{array}$ & $\begin{array}{c}0.00 \\
(0.28)\end{array}$ & $\begin{array}{c}0.00 \\
(0.29)\end{array}$ & $\begin{array}{c}0.03 \\
(0.31)\end{array}$ & $\begin{array}{l}-0.06 \\
(0.32)\end{array}$ & 22.63 & 0.7863 \\
\hline AM-TH & $\begin{array}{c}0.13 \\
(0.22)\end{array}$ & $\begin{array}{c}0.13 \\
(0.22)\end{array}$ & $\begin{array}{l}-0.09 \\
(0.23)\end{array}$ & $\begin{array}{l}-0.08 \\
(0.24)\end{array}$ & $\begin{array}{c}0.08 \\
(0.25)\end{array}$ & $\begin{array}{c}0.13 \\
(0.25)\end{array}$ & $\begin{array}{c}0.07 \\
(0.27)\end{array}$ & $\begin{array}{c}0.12 \\
(0.27)\end{array}$ & $\begin{array}{c}0.03 \\
(0.29)\end{array}$ & $\begin{array}{l}-0.03 \\
(0.29)\end{array}$ & $\begin{array}{l}-0.07 \\
(0.30)\end{array}$ & $\begin{array}{c}0.06 \\
(0.32)\end{array}$ & $\begin{array}{l}-0.07 \\
(0.34)\end{array}$ & 1.58 & 0.0783 \\
\hline HL-AM & $\begin{array}{c}0.57 \\
(0.12)\end{array}$ & $\begin{array}{c}0.11 \\
(0.13)\end{array}$ & $\begin{array}{l}-0.17 \\
(0.13)\end{array}$ & $\begin{array}{c}0.12 \\
(0.14)\end{array}$ & $\begin{array}{c}0.05 \\
(0.14)\end{array}$ & $\begin{array}{c}0.04 \\
(0.16)\end{array}$ & $\begin{array}{c}0.14 \\
(0.16)\end{array}$ & $\begin{array}{c}0.07 \\
(0.17)\end{array}$ & $\begin{array}{c}0.07 \\
(0.18)\end{array}$ & $\begin{array}{c}0.03 \\
(0.19)\end{array}$ & $\begin{array}{l}-0.02 \\
(0.19)\end{array}$ & $\begin{array}{l}-0.04 \\
(0.24)\end{array}$ & $\begin{array}{c}0.00 \\
(0.26)\end{array}$ & $\pi 7.47$ & 0.9908 \\
\hline HL-LM & $\begin{array}{c}0.65 \\
(0.27)\end{array}$ & $\begin{array}{l}-0.09 \\
(0.24)\end{array}$ & $\begin{array}{l}-0.10 \\
(0.25)\end{array}$ & $\begin{array}{l}-0.05 \\
(0.25)\end{array}$ & $\begin{array}{c}0.02 \\
(0.27)\end{array}$ & $\begin{array}{c}0.03 \\
(0.27)\end{array}$ & $\begin{array}{c}0.02 \\
(0.28)\end{array}$ & $\begin{array}{c}0.00 \\
(0.28)\end{array}$ & $\begin{array}{c}0.00 \\
(0.29)\end{array}$ & $\begin{array}{c}0.04 \\
(0.29)\end{array}$ & $\begin{array}{l}-0.08 \\
(0.32)\end{array}$ & $\begin{array}{l}-0.09 \\
(0.32)\end{array}$ & $\begin{array}{l}-0.07 \\
(0.32)\end{array}$ & 27.91 & 0.7692 \\
\hline HL-LL & $\begin{array}{c}0.65 \\
(0.18)\end{array}$ & $\begin{array}{c}0.10 \\
(0.19)\end{array}$ & $\begin{array}{c}0.13 \\
(0.19)\end{array}$ & $\begin{array}{c}0.04 \\
(0.19)\end{array}$ & $\begin{array}{l}-0.03 \\
(0.21)\end{array}$ & $\begin{array}{l}-0.07 \\
(0.21)\end{array}$ & $\begin{array}{c}-0.09 \\
(0.22)\end{array}$ & $\begin{array}{c}0.00 \\
(0.23)\end{array}$ & $\begin{array}{c}0.03 \\
(0.24)\end{array}$ & $\begin{array}{c}0.00 \\
(0.25)\end{array}$ & $\begin{array}{c}0.00 \\
(0.26)\end{array}$ & $\begin{array}{c}0.02 \\
(0.29)\end{array}$ & $\begin{array}{c}-0.04 \\
(0.29)\end{array}$ & 25.89 & 0.7838 \\
\hline HL-TH & $\begin{array}{l}-0.07 \\
(0.17)\end{array}$ & $\begin{array}{c}0.06 \\
(0.17)\end{array}$ & $\begin{array}{c}0.01 \\
(0.17)\end{array}$ & $\begin{array}{l}-0.04 \\
(0.19)\end{array}$ & $\begin{array}{l}-0.03 \\
(0.21)\end{array}$ & $\begin{array}{l}-0.10 \\
(0.22)\end{array}$ & $\begin{array}{c}0.00 \\
(0.23)\end{array}$ & $\begin{array}{c}0.05 \\
(0.23)\end{array}$ & $\begin{array}{c}0.05 \\
(0.24)\end{array}$ & $\begin{array}{c}0.01 \\
(0.27)\end{array}$ & $\begin{array}{c}0.01 \\
(0.27)\end{array}$ & $\begin{array}{c}0.03 \\
(0.31)\end{array}$ & $\begin{array}{l}-0.09 \\
(0.34)\end{array}$ & 1.06 & 0.0948 \\
\hline TH-AM & $\begin{array}{c}0.01 \\
(0.03)\end{array}$ & $\begin{array}{l}-0.07 \\
(0.04)\end{array}$ & $\begin{array}{c}0.07 \\
(0.07)\end{array}$ & $\begin{array}{l}0.02 \\
(08)\end{array}$ & $\begin{array}{c}0.04 \\
(0.08)\end{array}$ & $\begin{array}{c}0.09 \\
(0.10)\end{array}$ & $\begin{array}{c}0.00 \\
(0.10)\end{array}$ & $\begin{array}{c}0.01 \\
(0.11)\end{array}$ & $\begin{array}{l}-0.01 \\
(0.12)\end{array}$ & $\begin{array}{l}-0.02 \\
(0.14)\end{array}$ & $\begin{array}{c}0.00 \\
(0.14)\end{array}$ & $\begin{array}{c}0.02 \\
(0.15)\end{array}$ & $\begin{array}{l}-0.04 \\
(0.16)\end{array}$ & 1.09 & 0.0948 \\
\hline TH-HL & $\begin{array}{l}-0.07 \\
(0.08)\end{array}$ & $\begin{array}{c}0.12 \\
(0.09)\end{array}$ & $\begin{array}{c}0.11 \\
(0.09)\end{array}$ & $\begin{array}{c}0.04 \\
(0.09)\end{array}$ & $\begin{array}{c}0.11 \\
(0.10)\end{array}$ & $\begin{array}{c}0.09 \\
(0.10)\end{array}$ & $\begin{array}{l}-0.03 \\
(0.11)\end{array}$ & $\begin{array}{l}-0.02 \\
(0.13)\end{array}$ & $\begin{array}{l}-0.06 \\
(0.14)\end{array}$ & $\begin{array}{l}-0.06 \\
(0.16)\end{array}$ & $\begin{array}{c}0.11 \\
(0.17)\end{array}$ & $\begin{array}{c}0.03 \\
(0.19)\end{array}$ & $\begin{array}{l}-0.04 \\
(0.21)\end{array}$ & 0.95 & 0.0576 \\
\hline TH-LM & $\begin{array}{l}-0.08 \\
(0.10)\end{array}$ & $\begin{array}{c}0.11 \\
(0.11)\end{array}$ & $\begin{array}{c}0.08 \\
(0.11)\end{array}$ & $\begin{array}{c}0.11 \\
(0.14)\end{array}$ & $\begin{array}{c}0.00 \\
(0.15)\end{array}$ & $\begin{array}{c}0.00 \\
(0.15)\end{array}$ & $\begin{array}{l}-0.01 \\
(0.17)\end{array}$ & $\begin{array}{c}0.03 \\
(0.19)\end{array}$ & $\begin{array}{c}0.04 \\
(0.20)\end{array}$ & $\begin{array}{c}0.02 \\
(0.20)\end{array}$ & $\begin{array}{c}0.09 \\
(0.21)\end{array}$ & $\begin{array}{c}0.09 \\
(0.23)\end{array}$ & $\begin{array}{c}0.06 \\
(0.26)\end{array}$ & 0.09 & 0.0122 \\
\hline TH-LL & $\begin{array}{c}0.04 \\
(0.12)\end{array}$ & $\begin{array}{c}0.16 \\
(0.13)\end{array}$ & $\begin{array}{c}-0.04 \\
(0.13)\end{array}$ & $\begin{array}{c}0.05 \\
(0.13)\end{array}$ & $\begin{array}{c}0.09 \\
(0.15)\end{array}$ & $\begin{array}{c}0.10 \\
(0.16)\end{array}$ & $\begin{array}{l}-0.03 \\
(0.18)\end{array}$ & $\begin{array}{c}0.04 \\
(0.19)\end{array}$ & $\begin{array}{c}0.05 \\
(0.20)\end{array}$ & $\begin{array}{c}0.02 \\
(0.21)\end{array}$ & $\begin{array}{c}-0.10 \\
0.22)\end{array}$ & $\begin{array}{c}0.00 \\
(0.26)\end{array}$ & $\begin{array}{c}0.09 \\
(0.29)\end{array}$ & 0.0115 & \\
\hline
\end{tabular}

- The dependent variable is the current period residual rice price for the rice type and location indicated. That is, for example, AM denotes the residual rice price for medium grain rice

- The dependent variable is the current period residual rice price for the rice type and location indicated. That is, for example, AM denotes the residual rice price for medium grain rice milled in Arkansas. The explamatory variables are the

- The F-statistic 
Table 2b

Regression Results for Rice Price Residual Series: 1973-1986

\begin{tabular}{|c|c|c|c|c|c|c|c|c|c|c|c|c|c|c|c|}
\hline $\begin{array}{l}\text { Rice price residual } \\
\text { series (dependent } \\
\text { variable - explanatory } \\
\text { variable)(') }\end{array}$ & $\gamma_{0}$ & $\gamma_{1}$ & $\gamma_{2}$ & $\gamma_{3}$ & $\gamma_{4}$ & $\gamma_{s}$ & $\gamma_{6}$ & $\gamma_{7}$ & $\gamma_{B}$ & $\gamma_{9}$ & $\gamma_{10}$ & $\gamma_{11}$ & $\gamma_{12}$ & $F^{e}$ & $\mathbf{R}^{2}$ \\
\hline AM-LH & $\begin{array}{c}0.48 \\
(0.05)\end{array}$ & $\begin{array}{c}0.15 \\
(0.09)\end{array}$ & $\begin{array}{c}0.04 \\
(0.07)\end{array}$ & $\begin{array}{c}0.10 \\
(0.07)\end{array}$ & $\begin{array}{c}0.12 \\
(0.07)\end{array}$ & $\begin{array}{c}0.10 \\
(0.08)\end{array}$ & $\begin{array}{c}0.07 \\
(0.09)\end{array}$ & $\begin{array}{l}-0.07 \\
(0.09)\end{array}$ & $\begin{array}{c}0.05 \\
(0.09)\end{array}$ & $\begin{array}{l}-0.01 \\
(0.10)\end{array}$ & $\begin{array}{c}0.01 \\
(0.11)\end{array}$ & $\begin{array}{c}0.03 \\
(0.13)\end{array}$ & $\begin{array}{c}0.00 \\
(0.14)\end{array}$ & 14.48 & 0.8314 \\
\hline AM-LM & $\begin{array}{c}0.57 \\
(0.04)\end{array}$ & $\begin{array}{c}0.12 \\
(0.07)\end{array}$ & $\begin{array}{c}0.08 \\
(0.08)\end{array}$ & $\begin{array}{c}0.05 \\
(0.08)\end{array}$ & $\begin{array}{l}-0.02 \\
(0.09)\end{array}$ & $\begin{array}{l}-0.04 \\
(0.09)\end{array}$ & $\begin{array}{l}-0.01 \\
(0.10)\end{array}$ & $\begin{array}{c}0.01 \\
(0.11)\end{array}$ & $\begin{array}{c}0.05 \\
(0.13)\end{array}$ & $\begin{array}{l}-0.03 \\
(0.13)\end{array}$ & $\begin{array}{l}-0.02 \\
(0.13)\end{array}$ & $\begin{array}{c}0.02 \\
(0.14)\end{array}$ & $\begin{array}{c}0.06 \\
(0.16)\end{array}$ & 18.61 & 0.8524 \\
\hline AM-LL & $\begin{array}{c}0.43 \\
(0.08)\end{array}$ & $\begin{array}{l}0.05 \\
(0.08)\end{array}$ & $\begin{array}{c}0.07 \\
(0.09)\end{array}$ & $\begin{array}{c}0.07 \\
(0.09)\end{array}$ & $\begin{array}{c}0.07 \\
(0.09)\end{array}$ & $\begin{array}{c}0.10 \\
(0.09)\end{array}$ & $\begin{array}{l}-0.03 \\
(0.10)\end{array}$ & $\begin{array}{c}0.04 \\
(0.10)\end{array}$ & $\begin{array}{l}-0.02 \\
(0.14)\end{array}$ & $\begin{array}{l}-0.07 \\
(0.14)\end{array}$ & $\begin{array}{c}0.00 \\
(0.14)\end{array}$ & $\begin{array}{c}0.01 \\
(0.16)\end{array}$ & $\begin{array}{c}0.03 \\
(0.16)\end{array}$ & 21.10 & 0.8659 \\
\hline AM-TH & $\begin{array}{c}0.21 \\
(0.03)\end{array}$ & $\begin{array}{c}0.09 \\
(0.03)\end{array}$ & $\begin{array}{c}0.05 \\
(0.06)\end{array}$ & $\begin{array}{l}-0.05 \\
(0.07)\end{array}$ & $\begin{array}{c}0.04 \\
(0.07)\end{array}$ & $\begin{array}{c}0.11 \\
(0.10)\end{array}$ & $\begin{array}{c}0.02 \\
(0.11)\end{array}$ & $\begin{array}{l}-0.05 \\
(0.12)\end{array}$ & $\begin{array}{c}0.00 \\
(0.14)\end{array}$ & $\begin{array}{c}0.00 \\
(0.15)\end{array}$ & $\begin{array}{l}-0.04 \\
(0.15)\end{array}$ & $\begin{array}{c}0.05 \\
(0.17)\end{array}$ & $\begin{array}{c}0.07 \\
(0.17)\end{array}$ & 14.27 & 0.5936 \\
\hline HL-AM & $\begin{array}{c}0.68 \\
(0.09)\end{array}$ & $\begin{array}{c}0.14 \\
(0.11)\end{array}$ & $\begin{array}{c}0.17 \\
(0.11)\end{array}$ & $\begin{array}{c}0.02 \\
(0.12)\end{array}$ & $\begin{array}{c}0.05 \\
(0.12)\end{array}$ & $\begin{array}{l}-0.07 \\
(0.12)\end{array}$ & $\begin{array}{l}-0.05 \\
(0.14)\end{array}$ & $\begin{array}{c}0.02 \\
(0.15)\end{array}$ & $\begin{array}{c}0.11 \\
(0.15)\end{array}$ & $\begin{array}{c}0.04 \\
(0.15)\end{array}$ & $\begin{array}{l}-0.06 \\
(0.15)\end{array}$ & $\begin{array}{l}-0.04 \\
(0.15)\end{array}$ & $\begin{array}{c}0.07 \\
(0.15)\end{array}$ & 16.35 & 0.6141 \\
\hline HL-LL & $\begin{array}{c}0.69 \\
(0.11)\end{array}$ & $\begin{array}{c}0.01 \\
(0.12)\end{array}$ & $\begin{array}{c}0.02 \\
(0.13)\end{array}$ & $\begin{array}{c}0.08 \\
(0.13)\end{array}$ & $\begin{array}{c}0.02 \\
(0.14)\end{array}$ & $\begin{array}{l}-0.03 \\
(0.15)\end{array}$ & $\begin{array}{l}-0.02 \\
(0.15)\end{array}$ & $\begin{array}{c}0.03 \\
(0.16)\end{array}$ & $\begin{array}{c}0.03 \\
(0.16)\end{array}$ & $\begin{array}{c}0.04 \\
(0.16)\end{array}$ & $\begin{array}{l}-0.01 \\
(0.16)\end{array}$ & $\begin{array}{l}-0.04 \\
(0.17)\end{array}$ & $\begin{array}{l}-0.06 \\
(0.17)\end{array}$ & 24.43 & 0.8241 \\
\hline HL-TH & $\begin{array}{c}0.19 \\
(0.05)\end{array}$ & $\begin{array}{c}0.09 \\
(0.17)\end{array}$ & $\begin{array}{c}0.02 \\
(0.07)\end{array}$ & $\begin{array}{l}-0.08 \\
(0.09)\end{array}$ & $\begin{array}{c}0.03 \\
(0.09)\end{array}$ & $\begin{array}{c}0.02 \\
(0.11)\end{array}$ & $\begin{array}{c}0.01 \\
(0.11)\end{array}$ & $\begin{array}{c}0.05 \\
(0.11)\end{array}$ & $\begin{array}{c}0.05 \\
(0.11)\end{array}$ & $\begin{array}{c}0.00 \\
(0.14)\end{array}$ & $\begin{array}{c}0.00 \\
(0.15)\end{array}$ & $\begin{array}{c}0.01 \\
(0.16)\end{array}$ & $\begin{array}{l}-0.05 \\
(0.17)\end{array}$ & 13.60 & 0.5130 \\
\hline $\begin{array}{l}\text { TH-AM } \\
(0.04)\end{array}$ & $\begin{array}{c}0.15 \\
(0.04)\end{array}$ & $\begin{array}{c}0.06 \\
(0.05)\end{array}$ & $\begin{array}{c}0.00 \\
(0.05)\end{array}$ & $\begin{array}{c}0.01 \\
(0.06)\end{array}$ & $\begin{array}{c}0.00 \\
(0.06)\end{array}$ & $\begin{array}{c}0.04 \\
(0.07)\end{array}$ & $\begin{array}{l}-0.01 \\
(0.07)\end{array}$ & $\begin{array}{c}0.03 \\
(0.08)\end{array}$ & $\begin{array}{c}0.04 \\
(0.09)\end{array}$ & $\begin{array}{c}0.00 \\
(0.09)\end{array}$ & $\begin{array}{c}0.01 \\
(0.09)\end{array}$ & $\begin{array}{c}0.04 \\
(0.10)\end{array}$ & 0.02 & 13.53 & 0.4757 \\
\hline TH-HL & $\begin{array}{c}0.32 \\
(0.13)\end{array}$ & $\begin{array}{c}0.02 \\
(0.13)\end{array}$ & $\begin{array}{c}0.01 \\
(0.14)\end{array}$ & $\begin{array}{c}0.04 \\
(0.15)\end{array}$ & $\begin{array}{l}-0.01 \\
(0.05)\end{array}$ & $\begin{array}{l}-0.06 \\
(0.06)\end{array}$ & $\begin{array}{l}-0.07 \\
(0.06)\end{array}$ & $\begin{array}{c}0.01 \\
(0.07)\end{array}$ & $\begin{array}{c}0.01 \\
(0.08)\end{array}$ & $\begin{array}{c}0.03 \\
(0.09)\end{array}$ & $\begin{array}{c}0.05 \\
(0.09)\end{array}$ & $\begin{array}{c}0.03 \\
(0.10)\end{array}$ & $\begin{array}{c}0.01 \\
(0.10)\end{array}$ & 13.64 & 0.4814 \\
\hline TH-LM & $\begin{array}{c}0.33 \\
(0.13)\end{array}$ & $\begin{array}{c}0.02 \\
(0.13)\end{array}$ & $\begin{array}{c}0.03 \\
(0.13)\end{array}$ & $\begin{array}{c}0.01 \\
(0.13)\end{array}$ & $\begin{array}{l}-0.01 \\
(0.14)\end{array}$ & $\begin{array}{l}-0.09 \\
(0.14)\end{array}$ & $\begin{array}{l}-0.04 \\
(0.14)\end{array}$ & $\begin{array}{c}0.02 \\
(0.15)\end{array}$ & $\begin{array}{c}0.03 \\
(0.16)\end{array}$ & $\begin{array}{c}0.02 \\
(0.17)\end{array}$ & $\begin{array}{c}0.04 \\
(0.17)\end{array}$ & $\begin{array}{c}0.03 \\
(0.18)\end{array}$ & $\begin{array}{c}0.02 \\
(0.18)\end{array}$ & 14.37 & 0.4959 \\
\hline $\begin{array}{l}\text { TH-LL } \\
(0.15)\end{array}$ & $\begin{array}{c}0.38 \\
(0.16)\end{array}$ & $\begin{array}{c}0.06 \\
(0.16)\end{array}$ & $\begin{array}{c}0.00 \\
(0.16)\end{array}$ & $\begin{array}{c}0.01 \\
(0.16)\end{array}$ & $\begin{array}{l}-0.01 \\
(0.16)\end{array}$ & $\begin{array}{l}-0.06 \\
(0.17)\end{array}$ & $\begin{array}{l}-0.04 \\
(0.17)\end{array}$ & $\begin{array}{l}-0.07 \\
(0.17)\end{array}$ & $\begin{array}{c}0.01 \\
(0.17)\end{array}$ & $\begin{array}{c}0.01 \\
(0.17)\end{array}$ & $\begin{array}{c}0.06 \\
(0.17)\end{array}$ & $\begin{array}{c}0.07 \\
(0.17)\end{array}$ & 0.08 & 14.62 & 0.5030 \\
\hline
\end{tabular}

- The dependent variable is the current period residual rice price for the rice type and location indicated. That is, for example, AM denotes the residual rice price for medium grain rice milled in Arkansas. The explanatory variables are the lagged values of the dependent variable for twelve periods and the residual rice price for the current period and twelve previous periods for the second listed rice type and location.

- The F-statistic 
tions reported for the 1968-1972 period (see Table 2a) for milling centers in the United States (nor could it be rejected for any of the unreported estimates involving U.S. milling centers). That is, estimates of $a_{30}$ uniformly were statistically highly significant when various types of rice were considered at the different U.S. milling centers. Thus, there is only a single product market for all types of rice milled in the United States. Moreover, the finding that none of the other coefficients on the estimated relationship was statistically significant has implications in testing for unidirectional and bidirectional causality (which is not the present concern). ${ }^{16}$ [It should be noted that this result is not consistent with the results reported in Brorsen and Grant (1985)]. They found, for example, Arkansas prices affecting Houston prices but not the other way around (i.e., Houston prices did not affect Arkansas prices). That is, they found only unidirectional causality in some instances. ${ }^{17}$

The results of looking at rice produced in Thailand versus domestically produced rice also were quite revealing. During the period for which the U.S. price of rice was above the Thailand price due to the price support program of the U.S. govemment, the results indicated strongly that rice produced in Thailand was not in the same market as rice produced in the United States. That is, because the U.S. price support program for domestic rice maintained the price of rice in the U.S. at artificially high levels, the geographic extent of the market for U.S. produced rice was less it otherwise might have been.

The results were different for the 1973-1986 period when, as noted above, a wider variety of factors affected the quantity of rice produced in the world. Table $2 \mathrm{breports}$ the results of the instantaneous causality test for this period. These indicate that the geographic extent of the market broadened to include the entire world. That is, there were not two separate geographic markets - the U.S. and the rest of the world — as was the case in the 1968-1972 period, rather the world market for rice had become one. The inference that can be drawn from the application of the test for instantaneous causality is straightforward. Clearly, during the period 1973-1986 all types of rice in the various geographic locations were parts of the same market. That is, the null hypothesis that there is a single ricemarket in the world cannot be rejected. Price movements by one type of rice in one location are matched coincidentally by price movements in other types of rice at other locations within the same month. Moreover, no distributed lag process is involved. That is, there is no indication that two or more months are needed to exhaust the effects. ${ }^{18}$

One additional interesting consideration is the size of the coefficient $a_{30}$ for the various rice types and locations. The results for the 1973-1986 period suggest that the price interrelationships are strongest for the United States milling centers and weakest (but still statistically significant) for the U.S. and Thailand combinations. Thus, there is the suggestion that rice prices are related more strongly when the rice is milled in the United States than when it is processed in Thailand.

An alternative approach to examining the geographic and/or product extent of a market (which can serve as a point of reference for the results obtained here) has been touted by Stigler and Sherwin (1985). They proposed using simple correlation analysis and suggested that "If we find parallel price movements (as indicated by high correlations), the loci of the prices are in the same markets." With regard to the magnitude of the correlation coefficient necessary to conclude that two goods are in the same product market, no unique criterion was offered. It simply

Table 3a

Rice Price Correlations: 1968 - $1972^{\text {a }}$

\begin{tabular}{cccccc}
\hline \hline & $\mathrm{AM}^{\mathrm{b}}$ & $\mathrm{HL}$ & $\mathrm{LM}$ & $\mathrm{LL}$ & $\mathrm{TH}$ \\
\hline $\mathrm{AM}$ & 1.00 & 0.71 & 0.73 & 0.68 & 0.01 \\
$\mathrm{HL}$ & & 1.00 & 0.78 & 0.72 & 0.02 \\
$\mathrm{LM}$ & & & 1.00 & 0.84 & -0.02 \\
LL & & & & 1.00 & -0.01 \\
TH & & & & & 1.00 \\
\hline \hline
\end{tabular}

- The correlation matrix is symmetric.

b AM denotes the price of Arkansas medium grain price, etc. 
Table 3b

Rice Price Correlations: 1973 - 1986"

\begin{tabular}{llllll}
\hline \hline & AM $^{\circ}$ & HL & LM & LL & TH \\
\hline AM & 1.00 & 0.88 & 0.96 & 0.96 & 0.80 \\
HL & & 1.00 & 0.81 & 0.84 & 0.94 \\
LM & & & 1.00 & 0.99 & 0.81 \\
LL & & & & 1.00 & 0.78 \\
TH & & & & & 1.00 \\
\hline \hline
\end{tabular}

- The correlation matrix is symmetric.

b AM denotes the price of Arkansas medium grain price, etc.

was suggested that markets can show every level of interdependence and hence if a correlation coefficient of 0.9 makes two markets one, then a correlation of 0.7 or 0.8 implies a lesser degree of interdependence.

The correlations of the original price series for the five rice type/location combinations for the 1968-1972 period are presented in Table 3a and those for 1973-1986 are presented in Table 3b. Based on the examples provided by Stigler and Sherwin, the size of these correlation coefficients strongly suggests that there were two markets for rice, i.e. the rest of the world and the United States, during the first time period (1968-1972) and one world-wide market during the second time period (1973-1986).

These results are entirely consistent with those obtained via the test for instantaneous causality. As noted previously, however, simple correlation analysis of the type used by Stigler and Sherwin has been shown to provide misleading results when, for example, the price series exhibit strong trends or when two price series both are functions of some third variable. (See Pierce and Haugh (1977) for more on this.)

\section{Conclusion}

The foregoing analysis uses an approach to defining a market(s) for commodities based on the notion of instantaneous causality. The market(s) for which the approach is (are) empirically implemented is (are) the rice market(s) in the United States and in the rest of the world during the period 1968 1986. The empirical results, based on prices of different types of rice from four spatially diffuse locations, suggest that between 1968 and 1972, there were at least two separate, identifiable markets while between
1973 and 1986, there was but a single world market.

The product selected for analysis, namely milled rice, was chosen because the U.S. price exhibits an unusual relationship to the price of rice in the rest of the world. For the first five years of the sample period, the U.S. government price support was so high that it effectively precluded domestically produced rice from competing in the world market. For the remainder of the period, there was not such a disparity between the price in the rest of the world and the U.S. price so consequently there was but a single world market.

The implications of these results are straightforward and not very dramatic. In order for U.S. produced rice, or any agricultural commodity for that matter, to be an effective competitor in the world market, domestic price support programs must be structured so that the prevailing support price does not exceed the world price of the commodity in question. Thus, the guidelines under the Food Security Act of 1985 (U.S. Department of Agriculture (1986)) with regard to reducing the support price (i.e., the target price) may have to be lowered if the world price of a particular commodity puts U.S. output of that commodity in a position where it is unable to compete and hence is effectively eliminated from the world market.

\section{Notes}

'See Department of Justice (1984).

'That is, if the demand and supply determinants in the market(s) outside are independent of the demand and supply determinants within the market of interest, then prices are independently determined.

3That is, producers in the market can agree (either explicity or 
tacitly) and raise the price of the commodity without activating the economic forces (e.g., imports from other geographic area) that would negate any conclusive efforts. An analgous argument follows for delineating a product or product markets.

4See, e.g., Brorsen and Grant (1985), Horowitz (1981), Stigler and Sherwin (1985) and Uri and Rifkin (1985).

'It is useful to note that, in imperfectly competitive markets, marketing strategies tend to be associated with diversified firms producing branded products where price is only one element of many through which competition is carried out. Nevertheless, price is an ideal variable for investigating the extent of the market because it is the variable through which competition, to the extent it exists, is expressed most directly and via which response to competitive inroads are made most directly. Moreover, price is a quantitative measure whereas, if one elected to define a market on the basis of, say, consumer perceptions, an objective evaluation would be extremely difficult, if not impossible.

${ }^{6}$ See Uri and Rifkin (1985).

'See the exchange between Price (1979) and Pierce and Haugh (1979) that led to this conclusion.

${ }^{8}$ See U.S. Department of Agriculture, Rice: Outlook and Situation Report. September 1987.

'It is argued by Unnevehr (1986), among others that world markets are very important.

${ }^{10}$ Holder and Grant (1979) provide a chronology of rice legislation in the United States.

${ }^{11}$ In this analysis monthly data, were used. There is nothing, however, precluding the use of weekly or annual data. Ancillary analyses show the results generally are insensitive to the frequency of the data. In any application, however, the validity of this in the specific data set should be investigated.

${ }^{12}$ U.S. versus Rice Growers Association, et al., Civil No. 841066 EJG, E. District Califomia: Memorandum of Decision, May 1984.

${ }^{13}$ There are markets other than the one discussed here that can be considered. Thus, for example, it would be possible to consider the rough (unmilled) rice market or a market consisting of, say, milled rice and potatoes. For the purpose at hand, however, the empirical application focuses on the milled rice market(s).

${ }^{14}$ Classical least squares estimation was the preferred technique because there was no suggestion in preliminary analyses that the common problems in time series data (e.g., heteroscedasticity) were present here. That this is an acceptable approach given the conditions is dicussed by Geweke (1983).

${ }^{19}$ That is, the autoregressive coefficients are not statistically significantly different from zero at the 95 percent level or better. This (in conjunction with unreported partial F - statistics (i.e., for just the autoregressive terms)) indicates the absence of serial correlation. This adds further support to the appropriateness of classical least squares as the estimating technique.

${ }^{16}$ See, e.g., Geweke, et al. (1983).
${ }^{17}$ There are several incongruities in the Brorsen-Grant analysis and hence little attention is given to the apparent differences. The shortcomings include first differencing the (weekly) series without investigating the appropriateness of this, estimating univariate models via ordinary least squares (maximum likelihood is the preferred technique) and inappropriately using correlations to infer causality.

19t is important to note that there is no indication in the anlaysis concerning the extent of the market for factors of production used in the milled rice market. That is, one cannot conclude that, say, the market for rough rice is the world. A seperate analysis would be necessary before such a conclusion could be drawn. This simply recognizes that the market of interest can be competitive while the upstream and/or downstream markets can be imperfectly competitive. Scherer (1980) discusses these issues in great detail.

\section{References}

Areeda, P. and D.F. Turner. Antirust Law. Boston: Little, Brown and Co., 1978.

Box, G.E.P. and G.M. Jenkins. Time Series Analysis: Forecasting and Control. San Francisco: Holden-Day, 1971.

Brorsen, B.W., and W.R. Grant. "Efficiency of Spatial Price Discovery for U.U. Rice Under Different Farm Policies and Economic Conditions." Joumal of Policy Modeling. 7 (1985). 621- 633.

Brown, R.L., J. Durbin and J.M. Evans. "Techniques for Testing the Constancy of Regression Relationships Over Time." Joumal of the Royal Statistical Society. 37(1975). 149 - 163. Chamberlin, E.H. The Theory of Monopolistic Competition. Cambridge: Harvard University Press, 1962.

Department of Justice. Merger Guidelines. Washington: Department of Justice. June 14, 1984.

Geweke, J. "Inference and Causality in Economic Time Series Models" in Handbook of Econometrics, Z. Griliches and M. Intriligator (eds). Amsterdam: North Holland Publishing Company, 1983.

R. Meese, and W. Dent. "Comparing Alternative Tests of Causality in Temporal Systems: Analytic Results and Experimental Evidence." Journal of Econometrics. 21 (1983). 161-194.

Granger, C.W.J., and P. Newbold. Forecasting Economic Time Series. New York: Academic Press, 1977.

Haugh, L.D. The Identification of Time Series Interrelationships with Special Reference to Dynamic Regressions. Unpublished Ph.D. dissertation. Madison: University of Wiscon$\sin , 1972$.

Holder, S.H., and W.R. Grant. U.S. Rice Industry. Washington: U.S. Department of Agriculture, 1979.

Horowitz, I. "On Defining the Geographic Market in Section 7 Cases." Bank Structure and Competition. 12(1977). 169- 
182.

"Market Definition in Antitrust Analysis: A Regression Based Approach." Southern Economic Journal. 48 (1981). 1-16.

Jevons, W.S. The Theory of Political Economy. London: Macmillan and Company, 1879.

Kaldor, N. "Mrs. Robinson's Economics of Imperfect Competition." Economica (New Series). 36 (1934), 335 341.

Pierce, D.A., and L.D. Haugh. "Causality in Temporal Systems." Journal of Econometrics. 5 (1977), 265-293. and L.D. Haugh. "The Characterization of Instantaneous Causality." Joumal of Econometrics. 7 (1979), 257- 259.

Price, J.M. "The Characterization of Instantaneous Causality." Journal of Econometrics. 7 (1979), 253-256.

Robinson, J. The Principles of Imperfect Competition. New York: St. Martin's Press, 1969.
Scherer, F.M. Industrial Market Structure and Economic Performance, 2nd ed. Chicago: Rand McNally, Inc. 1980.

Stigler, G., and R. Sherwin. "The Extent of the Market." Joumal of Law and Economics. 28 (1985), 555-585.

U.S. Department of Agriculture. Rice: Outlook and Situation Report. Washington: Economic Research Service, Washington (March and September annually).

Provisions of the Food Secu-

rity Act of 1985. Washington: Economic Research Service, 1986.

Unnevehr, L.J.. "Consumer Demand for Rice Grain Quality and Returns to Research for Quality Improvement in Southeast Asia." American Joumal of Agricultural Economics. 68 (1986), 634-641.

Uri, N.D. and E. Rifkin, "Geographic Markets, Causality and Railroad Deregulation" The Review of Economics and Statistics. 67 (1985), 422-428. 